\title{
Charismatic leadership and democracy in the Caribbean Basin: the constitutional legacies of Arnulfo Arias and Luis Muñoz Marín
}

\author{
Carlos Guevara Mann \\ Universidad del Norte, Barranquilla, Colombia
}

\begin{abstract}
Charismatic leadership contributed to the shaping of politics in Panama and Puerto Rico, in particular through the careers of Arnulfo Arias and Luis Muñoz Marín, respectively. Based on an examination of their trajectories, this paper seeks to further illuminate the relationship between charismatic leadership and democracy. As suggested by Weber, as argued by the literature on Latin American populism and personalism, and as shown by Arias's political legacy, the 'charismatic mission' can promote plebiscitary democracy. But can charismatic authority also foster representative democracy? Muñoz Marín's career provides interesting insights in this regard.
\end{abstract}

Keywords: charismatic leadership, plebiscitary or delegative democracy, liberal or representative democracy, Arnulfo Arias, Luis Muñoz Marín

\section{INTRODUCTION}

Can charismatic leadership help produce democracy? If so, what type of democracy is it likely to help generate? These questions about the nexus between charisma and 'government by the people' are significant for at least three reasons: because democracy is desirable; because leadership is an aspect of all political regimes (including democracy); and because many examples of leadership, especially in Latin America, exhibit charismatic traits. Indeed, according to some observers, a new wave of charismatic politics has swept through Latin America in recent years, adding members to the region's pantheon of personalist leaders whose success is based on the powerful attraction they exercise over a devoted following.

This paper seeks to contribute to the debate about the impact of leadership on political regimes by focusing on the careers of two charismatic leaders active simultaneously in the Caribbean Basin. They operated in Panama and Puerto Rico, two countries heavily influenced by the United States, albeit to different degrees. For, while Panama, an independent republic since 1903, has been firmly within the US sphere of influence for most of its contemporary history, Puerto Rico was annexed by Washington in 1898 and has remained part of the United States ever since.

As shown by Arnulfo Arias's career in Panama, charismatic leadership may help promote a plebiscitary or 'delegative' model of democracy. For one who values the democratic system, such an outcome might be considered a setback if it represented an erosion of a liberal democracy already in place. But it might be deemed an improvement if plebiscitary democracy constituted a progression from a non-democratic form 
of government, such as a military autocracy or an oligarchy. ${ }^{1}$ As shown by the career of Luis Muñoz Marín in Puerto Rico, charismatic leadership may also help foster representative democracy. Based on Weber's theorizations about charismatic leadership, however, this is not a likely outcome. Thus, it merits close examination.

This paper posits that charismatic leadership may contribute to the development of democracy, either of the plebiscitary or of the representative type. The degree of executive power, as indicated in the constitutions introduced by Arias and Muñoz Marín, helps ascertain which type of democracy the charismatic mission contributes to bring about. In order to develop these arguments, the paper first presents certain notions of democracy and charismatic authority that are directly relevant to the discussion (Sections 2-3). Based on these notions, it then proceeds to make theoretical connections between democracy and charismatic leadership that will later illuminate the analysis of the careers of Arnulfo Arias and Luis Muñoz Marín (Section 4). Next comes a summary of the history of Panama and Puerto Rico in the twentieth century, followed by biographies of both leaders (Sections 5-7). The subsequent section (8) aims at identifying the charismatic elements in the careers of Arias and Muñoz Marín.

An examination of these leaders' constitutional legacies - which helps substantiate the point that Arias's mission promoted a plebiscitary model of democracy while Muñoz Marín's leadership encouraged liberal, representative democracy - follows (Section 9). Though several indicators of plebiscitary and representative democracy may be employed, this paper focuses on the strength of executive power in the constitutions introduced by both charismatic leaders: Panama's constitution of 1941 and Puerto Rico's fundamental law of $1952 .^{2}$ At that stage, the analysis is guided by the assumption that a leader inclined toward a plebiscitary model of democracy is likely to advocate a more powerful executive, while one favoring a representative model is likely to promote a less vigorous executive; that is, one more subject to controls by institutions of horizontal accountability. Shugart and Carey's index of the powers of popularly elected presidents serves to measure the strength of executive power (Shugart and Carey 1992, pp. 148-158). The paper's concluding section (10) assesses the contributions of both leaders to the democratic development of their countries and offers tentative explanations of their preference for one or the other version of democracy.

\section{DEMOCRACY: REPRESENTATIVE AND PLEBISCITARY}

As an institutional arrangement aimed at maximizing government responsiveness to the popular will, democracy is a desirable goal. Dahl notes that the democratic process 'promotes freedom as no feasible alternative can' (Dahl 1989, p. 311). Democracy also encourages human development better than non-democracy and is the surest way (if by no means a perfect one) by which human beings can protect and advance the interests and goods they share with others' (ibid.).

Democracy, says Dahl, is a political system whose members 'regard one another as political equals, are collectively sovereign, and possess all the capacities, resources, and institutions they need in order to govern themselves' (Dahl 1989, p. 311). The institutions of democracy include, at a minimum, those pertaining to what Dahl terms

1. I thank Aníbal Pérez Liñán for this insight.

2. Derek Kauneckis suggested the convenience of this framework. 
'polyarchy' (elected officials, free and fair elections, inclusive suffrage, the right to run for office, freedom of expression, access to alternative sources of information, associational autonomy) (ibid., p. 221). According to O'Donnell, the first four attributes 'tell us that a basic aspect of polyarchy is that elections are inclusive, fair, and competitive.' The remaining three 'refer to political and social freedoms that are minimally necessary not only during but also between elections as a condition for elections to be fair and competitive' (O'Donnell 1996, p. 35).

For Norberto Bobbio, representative democracy is a political system in which 'collective deliberations, i.e. deliberations which concern the whole community, are taken not directly by its members, but by people elected for this purpose' (Bobbio 1987, p. 45). Those who exercise political representation include the head of government (an elected president or prime minister) as well as members of deliberative assemblies, local governments, and other political organizations (ibid.). Dahl observes that the notion of representative government, formulated in the eighteenth century, constitutes the key to the establishment of modern democracy. Before the founders of the United States came up with the concept of democratic representation, the only known democratic model was direct democracy, practiced in small political communities. Large territory and population made it impracticable in the nation-states that emerged in the modern era. By assigning the tasks of government to a small proportion of the political community through democratic elections, however, representation solved the problem of 'how to combine democracy with the large state' (Dahl 1971, pp. 169-170).

Representative democracy entrusts decision-making authority to elected representatives. While such assignment of authority runs contrary to the idea of popular participation in decision-making inherent in direct democracy, representative democracy remains a democratic form through the notion of accountability. In representative democracy, the institutions of vertical and horizontal accountability ensure that the activities of officeholders operate under the control of the citizenry and within the constitutional sphere (Judge 1999, pp. 7-12). Civil society helps ensure accountability by 'encouraging the creation and empowerment of institutional checks and balances' and 'by strengthening the institutions of vertical accountability that underpin them, such as electoral democracy and an independent media' (Fox 2000, p. 1). ${ }^{3}$

Inclusive, fair, competitive, and periodic elections are the quintessential institution of vertical accountability. Horizontal accountability, which occurs between elections,

is usually manifest in the monitoring, investigating, and enforcement activities of a number of independent government agencies: the opposition in parliament; parliamentary investigative committees; the various tiers of the court system, including, crucially, the constitutional court; audit agencies; counter-corruption commissions; the central bank; an independent electoral administration, the ombudsman, and other bodies that scrutinize and limit the power of those who govern. (Diamond and Morlino 2005, p. xxi)

Here lies the basic distinction between representative and plebiscitary (or delegative) democracy. In both democratic forms the citizenry delegate their decision-making authority. In both types, as well, officeholders remain accountable to the people through vertical accountability. In plebiscitary democracy, however, the institutions of horizontal accountability are weaker than in representative democracy. Though a democratic form of government, plebiscitary democracy is 'less liberal' than

3. An anonymous reviewer for Leadership and the Humanities suggested reference to the role of civil society in promoting accountability. 
representative democracy (O'Donnell 1994, p. 60). In his definition of delegative democracy, O'Donnell (ibid., pp. 59-60) sums up the essence of plebiscitarianism:

Delegative democracies rest on the premise that whoever wins election to the presidency is thereby entitled to govern as he or she sees fit, constrained only by the hard facts of existing power relations and by a constitutionally limited term of office. The president is taken to be the embodiment of the nation and the main custodian and definer of its interests ... In this view, other institutions - courts and legislatures, for instance - are nuisances that come attached to the domestic and international advantages of being a democratically elected president. Accountability to such institutions appears as a mere impediment to the full authority that the president has been delegated to exercise.

Taking this argument a step further, we can assume that the executive in a plebiscitary democracy has stronger (formal or informal) powers than in a representative democracy. This assumption indicates the convenience of utilizing a measure of executive power to help elucidate plebiscitary or representative tendencies in a regime. Shugart and Carey (1992) provide such a framework to measure the extent of the formal powers of the executive.

\section{CHARISMATIC LEADERSHIP}

Charisma is one of the three sources of authority or legitimate domination identified by Weber. Intrigued by the reasons that prompt people to willingly obey, Weber recognized three 'ideal' or pure types of legitimate domination: legal-rational, traditional, and charismatic authority. Legal-rational authority is the voluntary submission of the members of an organization to an impersonal order. It is founded on a series of written legal norms that are impartially applied to particular cases. Legal-rational authority is exercised through a professional, technically qualified, and normally monocratic bureaucracy (that is, one that is subject to a single head), operating in accordance with formal rules and regulations voluntarily accepted by those subject to them.

Authority is traditional, on the other hand, if 'legitimacy is claimed for it and believed in by virtue of the sanctity of age-old rules and powers' (Weber 1922 [1978], p. 226). Charismatic authority - Weber's third type - flows from the extraordinary powers or qualities of an individual recognized as leader by a political association or community. The term 'charisma,' says Weber (ibid., p. 241), may be applied 'to a certain quality of an individual personality by virtue of which he is considered extraordinary and treated as endowed with supernatural, superhuman, or at least specifically exceptional powers or qualities. These [qualities] are not accessible to the ordinary person, but are regarded as of divine origin or exemplary, and on the basis of them the individual concerned is treated as a "leader."

In other words, the outstanding traits recognized in an individual make him or her deserve obedience. Followers regard charismatic leaders as 'bearers of specific gifts of body and mind that [are] considered supernatural' (Weber 1922 [1978], p. 1112). Continued recognition of these qualities is the basis of charismatic authority, which translates into a strong emotional attachment to the leader and strict adherence to his (or her) commands (ibid., pp. 215, 269, and 1112).

Weber associates charismatic leadership with informality, temporality, authoritarianism, irrationality, arbitrariness, and personalism. According to Weber, charismatic authority lacks 'formal rules' or 'abstract legal' standards (ibid., p. 243). It is basically a temporary arrangement: 'Charisma is by nature not a continuous institution, but in its 
pure type the very opposite' (ibid., p. 1113). The principle of charismatic legitimation is 'basically authoritarian': recognition by followers is their duty (ibid., p. 266). The purely charismatic type of domination is also 'foreign to all rules,' as it is not 'bound to intellectually analysable' statutes (ibid., p. 244). Thus it is arbitrary and emotional or irrational (in the sense that it does not conform to a legal-rational decision-making process, based on scientific deduction and empirical observation). ${ }^{4}$ Because it repudiates the past, charismatic authority is 'a specifically revolutionary force' (ibid., p. 244). Its social relationships 'are strictly personal' (ibid., p. 246).

\section{CHARISMA AND DEMOCRACY}

The relationship between charismatic leadership and democracy is relevant because leadership is an inherent part of all political arrangements (including democracy). Analysts have underscored the crucial contributions of leadership in the historical processes resulting in democratization (or re-democratization). Dahl (1989, p. 261), for example, suggests that given the 'rather rudimentary' political beliefs of most people, policy outcomes are often the result of leaders' value-oriented actions and choices. For Linz (1978, pp. 87-88), leadership is a key variable contributing to explain the breakdown, re-equilibration, and restoration of democratic regimes.

Following Weber's conceptualizations, we know that a charismatic mission can lead to authoritarianism or totalitarianism, as the examples of Mussolini and Hitler readily demonstrate. Might it also help bring about some form of democracy? While Gandhi's charismatic leadership points in that direction, the question is especially significant for Latin America, a region where the political repertoire includes charismatic political leaders who have exerted a profound influence in public affairs.

Charismatic authority has been considered a characteristic feature of Latin American politics ever since the region obtained release from Iberian domination in the early nineteenth century. As a result, the links between this form of leadership and democracy received some attention in the literature. Studies of classic twentiethcentury charismatic leaders such as Eva and Juan Perón (Argentina), José María Velasco Ibarra (Ecuador), Jorge Eliécer Gaitán (Colombia), and Getulio Vargas (Brazil), among others, serve to shed light on the impact of these individuals' leadership on the political life of their countries. ${ }^{5}$ With a resurgence of charismatic leadership in recent years,

\section{I thank John Marini for this insight.}

5. The literature on these leaders is extensive. On Eva and Juan Perón, see Robert J. Alexander, Juan Domingo Peron: A History (Boulder: Westview Press, 1979); John de Chancie, Juan Peron (World Leaders Past \& Present) (London: Chelsea House Publications, 1988); Robert Crassweller, Peron and the Enigmas of Argentina (New York: W.W. Norton, 1988); Alicia Dujovne Ortiz and Shawn Fields, Eva Peron (London: St Martin's Press, 1996); Nicholas Fraser and Marysa Navarro, Evita: The Real Life of Eva Peron (New York: W.W. Norton, 1996); Douglas Madsen and Peter Snow, The Charismatic Bond: Political Behavior in Time of Crisis (Cambridge, MA: Harvard University Press, 1991); Joanne Mattern, Eva Peron (London: Chelsea House, 2010); Joseph Page, Perón: A Biography (New York: Random House, 1983); Kremena Spengler, Eva Peron: First Lady of the People (North Mankato, MN: Capstone Press, 2006); Darlene Stille, Eva Peron: First Lady of Argentina (Mankato, MN: Compass Point Books, 2006); and Frederick C. Turner and Jose Enrique Miguens, Juan Peron and the Reshaping of Argentina (Pittsburgh: University of Pittsburgh Press, 1983). On Perón and Getúlio Vargas, see Alejandro Groppo, The Two Princes: Juan D. Peron and Getulio Vargas: A Comparative Study of Latin American Populism (Villa María, Argentina: EDUVIM, 2013). On José María Velasco Ibarra, see Carlos de La Torre, 
particularly in Venezuela (Hugo Chávez) and, according to some, in Bolivia (Evo Morales), Colombia (Alvaro Uribe), and Ecuador (Rafael Correa) as well, analysts have focused more carefully on the links between charismatic authority and democracy at a time when all but one of the region's countries are electoral or liberal democracies.

At first sight, charismatic leadership does not seem conducive to formal political, including democratic, institutionalization. Political institutionalization refers to the process whereby 'organizations and procedures acquire value and stability' (Huntington 1968, p. 12). It is a historical development ending in the solidification of patterns of behavior, in the course of which these patterns slowly lose their character as a 'tool,' becoming valuable in and of themselves (Panebianco 1988, pp. 49 and 53). The process of value acquisition is significant for democratic institutionalization because as a result of it the institutions of democracy become legitimated and ingrained in society.

A leadership style the pure type of which is highly emotional, revolutionary, arbitrary, and based on personal relationships appears to be antithetical to the legal-rational processes of formal institution building. Weber, however, suggests that charismatic authority might eventually become institutionalized - through traditionalization or legalization - after the leader's disappearance. He calls this process - normally undertaken by the leader's staff or close relatives - the 'routinization' of charisma. Interested in pursuing their ideal and material interests, the staff might succeed in transforming the charismatic 'mission' into an office, 'which may develop a patrimonial or bureaucratic character' (Weber 1922 [1978], p. 251). In modern, mass societies, the process of routinization might institutionalize the 'mission' in a political party, after the loss of the leader. Figure 1 provides a possible diagram of this process.

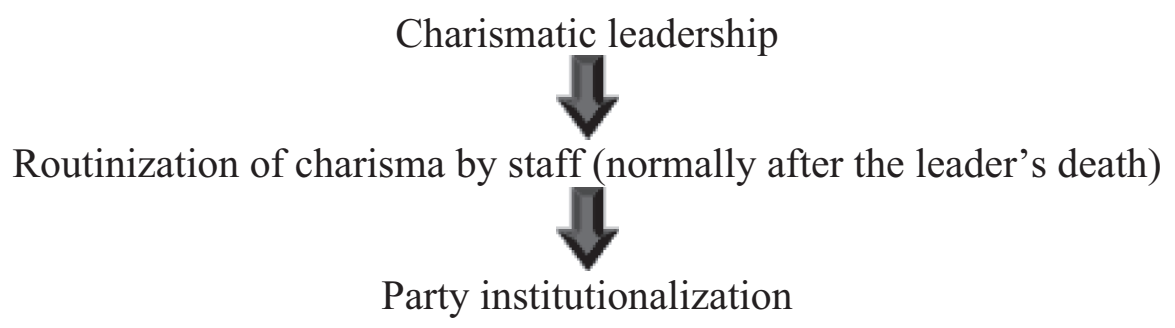

Source: Adapted from Weber 1922 [1978]).

Figure 1 Progression from charismatic leadership to party institutionalization (according to Max Weber)

La seducción velasquista (Quito: Ediciones Libri Mundi, 1993) and Robert E. Norris and Carlos de La Torre, El gran ausente: biografía de Velasco Ibarra (Quito: Ediciones Libri Mundi, 2004). On Jorge Eliécer Gaitán, see Herbert Braun, The Assassination of Gaitan: Public Life and Urban Violence in Colombia (Madison: University of Wisconsin Press, 1986) and Richard E. Sharpless, Gaitán of Colombia: A Political Biography (Pittsburgh: University of Pittsburgh Press, 1978). On Getúlio Vargas, see Jens R. Hentschke, ed., Vargas and Brazil: New Perspectives (New York: Palgrave Macmillan, 2006); Robert Levine, The Vargas Regime: The Critical Years 1934-1938 (New York: Columbia University Press, 1970); Robert Levine, Father of the Poor? Vargas and his Era (Cambridge, UK: Cambridge University Press, 1998); and R.S. Rose, One of the Forgotten Things: Getulio Vargas and Brazilian Social Control, 1930-1954 (Westport, CT: Praeger, 2000). 


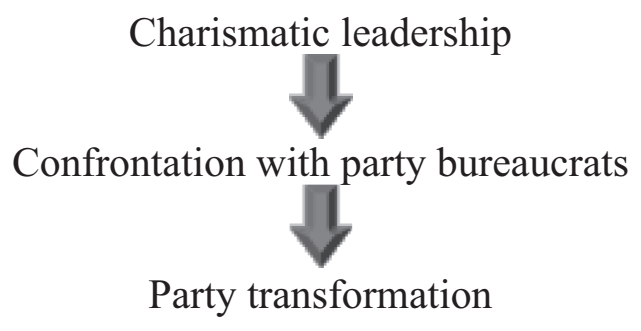

Source: Adapted from Weber (1922 [1978]).

Figure 2 Effects of charismatic leadership arising within a party (according to Max Weber)

Yet another possibility entertained by Weber is the emergence of charismatic leadership within a 'solidly bureaucratized' political party (not within society at large). 'If there is a "hero," Weber explains, 'he will endeavor to break the technicians' hold over the party by imposing plebiscitary designation and possibly by changing the whole machinery of nomination' (ibid., p. 1132, emphasis added). A confrontation is bound to ensue between the charismatic leader and the party bureaucrats and bosses. Who emerges victorious from the struggle depends on the 'character' of the party whether it is a 'catch-all,' patronage-seeking party; a party of notables; or an ideological party. 'In certain respects,' says Weber, 'the chances of charisma are greatest in the first case,' that is, in a 'catch-all' party (ibid., p. 1133). Weber does not explain how charismatic authority surfacing in a bureaucratized party might evolve. But, because of the revolutionary nature of charismatic leadership, it is bound to produce momentous transformations in the structure of the party. Figure 2 provides a likely diagram of this process.

In this discussion, Weber's reference to a charismatic leader's rise to power within a party through 'plebiscitary designation' is directly relevant to our discussion. According to Weber, in plebiscitary democracy '[t]he leader (demagogue) rules by virtue of the devotion and trust which his political followers have in him personally' (ibid., p. 268). (Note that 'devotion and trust' are traits of charismatic leadership.) After providing historical examples of plebiscitary rule - 'the dictatorship of Cromwell, and the leaders of the French Revolution and of the First and Second Empire' - Weber goes on to say: 'Wherever attempts have been made to legitimize this kind of exercise of power, legitimacy has been sought in recognition by the sovereign people through a plebiscite' (ibid., p. 1132). Figure 3 provides a possible diagram of this process.

To recapitulate, for Weber, charismatic leadership - though an irrational, antibureaucratic, arbitrary, revolutionary force - may emerge in modern, mass societies. If it sprouts within a political party, charismatic leadership may transform it in unspecified ways. A charismatic mission may also rise outside a party, in society at large. Through routinization, generally occurring after the disappearance of the leader, charisma might become institutionalized in a political party.

Through popular acclamation, charismatic leadership may result in plebiscitary rule. If acclamation occurs through a democratic process containing Dahl's seven attributes (see above), the result might be 'plebiscitary' or 'delegative democracy.' Weber, however, was suspicious of the democratic credentials of plebiscitarianism: 'Regardless of how its real value as an expression of the popular will may be regarded, the plebiscite 


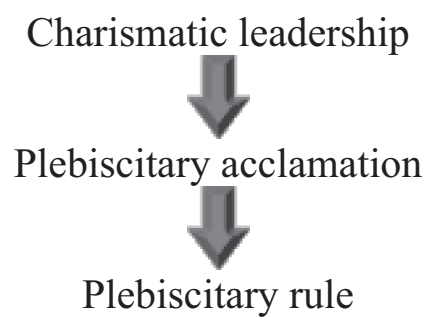

Source: Adapted from Weber (1922 [1978]).

Figure 3 Legitimization of charismatic leadership through plebiscitary acclamation (according to Max Weber)

has been the specific means of deriving the legitimacy of authority from the confidence of the ruled, even though the voluntary nature of such confidence is only formal or fictitious' (Weber 1922 [1978], p. 267).

Weber did not recognize relationships between charismatic authority and representative democracy. Based on his characterization of 'parliamentary representation' as sharing 'the general tendency to impersonality' and 'the obligation to conform' to the political or ethical 'abstract norms' of legal authority (ibid., p. 294), the reader is left with the impression that charismatic leadership and representative democracy are a difficult mix. Representative government is impersonal and rule-bound. Charismatic authority is personalistic and irrational.

Recent scholarship on charismatic leadership in Latin America concurs with the Weberian framework presented above. In his article on 'The Missionary Politics of Hugo Chávez,' for instance, José Pedro Zúquete (2008, p. 114) emphasizes that replacing 'representative democracy ... derided as formal and false' with 'a new, direct, participatory democracy' was one of the goals of Chávez's 'missionary' leadership. Zúquete's concept of 'missionary' politics is useful in that it provides a pure type encompassing both charismatic authority and populism (ibid., p. 96), the political strategy associated with personalist leadership in an electoral context. Other authors do not distinguish between populism and charismatic authority as clearly as does Zúquete, often using both labels interchangeably.

La Torre's (2013) article on Ecuador, for example, sees populism as a 'paradigmatic case of charismatic domination' (ibid., p. 26). Focusing on the leadership of Rafael Correa, he observes that while populism (as an instance of charismatic authority) 'incorporates sectors previously excluded from politics,' it shows 'selective respect for the norms and procedures of liberal democracy' (ibid., p. 27). Additionally, it 'rejects the mediation of representative democracy and seeks to establish direct channels of communication between the leader and his people' (ibid.). Furthermore, '[i]n fragile political systems populism can have adverse effects on democracy' (ibid.).

The conclusion obtained from reading these and other assessments of charismatic leadership is that while it might foster a version of direct or participatory democracy, it does not blend well with liberal, representative democracy. These views are consistent with Weber's now classic rendition of political charisma. Is, however, plebiscitary democracy the only democratic model charismatic leadership can bring about? Might a charismatic mission also help foster representative democracy? This paper sheds light on these issues by comparing the careers of two charismatic, contemporaneous leaders 
of the Caribbean Basin: Arnulfo Arias and Luis Muñoz Marín. As these leaders operated in specific political scenarios, and before delving into their biographies, brief political timelines for Panama and Puerto Rico will help the reader situate Arias and Muñoz Marín in their respective contexts.

\section{POLITICAL TIMELINES: PANAMA AND PUERTO RICO}

Over 300 years of Spanish rule ended in Panama in 1821, when the urban patriciate of Panama City declared the isthmus independent from Spain and union to Simón Bolívar's Republic of Colombia (comprising present-day Colombia, Ecuador, and Venezuela). When this entity collapsed in 1830, Panama also seceded but shortly afterwards reunited with New Granada (as present-day Colombia was then called). Attempts to create an independent or autonomous Panamanian state occurred throughout the nineteenth century, culminating in 1903. With strong US encouragement, Panama then became an independent republic and established a republican regime under Washington's tutelage.

The 1904 Constitution - modeled after Colombia's charter of 1886 - established a strong executive, a weak National Assembly, and US domination over the fledgling state, whose territory Washington would soon slice to provide a major route for US shipping. A provision whereby the United States agreed to 'protect' the country's independence remained in the constitution until Arnulfo Arias replaced the 1904 statute with his 1941 charter. Though fraud often tarnished Panama's elections, governments assumed and left office with constitutional regularity up to 1931. That year, a coup d'état (led by Arias) deposed the incumbent president. Despite the 'protectorate' clause, the United States did not intervene militarily to prevent the overthrow, but pressed to 'constitutionalize' a transfer of power through the Panamanian Supreme Court's appointment of a caretaker administration.

Fraud and manipulation remained features of Panama's electoral system up to the transition to democracy in 1989-1994. So did forceful removals of incumbents. In 1941, after President Arnulfo Arias's removal, his extra-constitutional successor placed the country under de facto rule until 1945. A Constituent Assembly convoked that year returned the country to constitutional rule and promulgated the statute of 1946, which replaced Arias's 1941 Constitution. Even so, intervention by the National Police (later National Guard) in the country's political affairs intensified in the late 1940s and early 1950s, culminating with Arias's second removal (1951) and the tainted election of Police Chief José Remón as president in 1952.

Politics became less unstable and more democratic for a few years after Remón's assassination in 1955 (Guevara Mann 1996; Pippin 1964). On the Polity IV classification - a broadly accepted measure of the autocratic or democratic nature of political regimes ranging between -10 (highly autocratic) to +10 (highly democratic) - Panama's score improved from -1 in 1949-1954 to +4 in 1955-1967 (Marshall et al. 2014). Despite progress towards democracy in the late 1950s and early 1960s, towards the end of the decade a US-supported military coup once again overthrew Arnulfo Arias (elected in 1968) and established rule by the National Guard, which would last until 1989. Dictators Omar Torrijos (1968-1981), Rubén Paredes (1982-1983), and Manuel Noriega (1983-1989) utilized varying degrees of repression in response to demands for democracy. The military regime promulgated a new constitution in 1972 which, after reforms in 1978, 1983, 1994, and 2004, remains Panama's fundamental law to this day (Guevara Mann 1996).

The overthrow of Manuel Noriega's dictatorship by a US invasion in 1989 allowed a transition to democracy culminating with elections in 1994, considered free and fair. 
Table 1 Polity IV scores for Panama, 1903-2013

\begin{tabular}{lc}
\hline Period & Score \\
\hline $1903-1948$ & -3 \\
$1949-1954$ & -1 \\
$1955-1967$ & 4 \\
$1968-1977$ & -7 \\
$1978-1981$ & -6 \\
$1982-1983$ & -5 \\
$1984-1986$ & -6 \\
$1987-1988$ & -8 \\
$1989-1993$ & 8 \\
$1994-2013$ & 9 \\
\hline
\end{tabular}

Note: The shaded cells represent scores for the military dictatorship.

Source: Marshall et al. (2014).

Panama has been classified as a democracy ever since. To better illustrate the general political context in which Arnulfo Arias's charismatic leadership operated, Table 1 summarizes Polity IV scores for Panama in 1903-2013.

Spanish government lasted longer in Puerto Rico than in Panama. Almost 400 years of Iberian rule ended with the Spanish-American War of 1898, the year Luis Muñoz Marín was born in San Juan. Following the US victory in the brief conflagration, a peace treaty signed in Paris that year placed Puerto Rico under Washington's direct control. This is an important distinction from Panama, one which influenced the context in which Muñoz Marín was able to operate. While both countries were subject to US influence, Panama was nominally independent. Moreover, after Washington changed its policy of direct military intervention in its sphere of influence, in the late 1920s, Panama - while still dependent on the United States - obtained a greater measure of autonomy. Puerto Rico, however, was part of the United States.

In subsequent years, under direct US rule, politics were more orderly in Puerto Rico than in the isthmian republic. In the absence of Polity IV scores for Puerto Rico, it is difficult to ascertain the democratic character of these politics comparatively. ${ }^{6}$ Although civil rights were generally in place, the people of Puerto Rico did not enjoy the right to a fully elected government during the 50 years following the transfer of sovereignty. Based on Dahl's criteria for polyarchy, Puerto Rico would not qualify as a democracy in 1898-1948.

In 1900, the Foraker Act of the US Congress instituted a civil government appointed by the US president as well as a Legislative Assembly with an elected lower house. In 1917, the Jones Act instituted elections for the upper house of the legislature (henceforth called the Puerto Rican Senate) and granted US citizenship to the inhabitants of the island. Subsequently, demands for self-rule or outright independence increased in the 1930s and 1940s. Washington, however, did not permit internal selfgovernment until 1948 when a bill introduced the previous year in the US Congress allowed the people of Puerto Rico to elect their own government. Puerto Ricans have exercised that right ever since.

6. Polity IV only provides data for independent states. 
In 1952, under the aegis of Muñoz Marín, Puerto Rico obtained its own constitution and legal status as a 'commonwealth' in voluntary association with the United States. According to this compact, the people of Puerto Rico manage their internal affairs through elected representatives. Washington handles matters normally entrusted to the federal government within the Union, especially those related to foreign relations, international trade, and military matters. Puerto Ricans living in Puerto Rico are exempt from paying US federal income tax, but have no voting representatives in the US Congress (only a non-voting 'resident commissioner' in the House of Representatives) and cannot vote in US federal elections (Morris 1995).

Throughout the period when Muñoz Marín emerged as a leader, therefore, the island conducted its politics under direct US supervision. The nature of Washington's control in Puerto Rico gave an impetus to democracy along US lines. Although there were outbursts of nationalist violence from the 1930s to the 1950s, Washington's supervision weakened the viability of extra-constitutional solutions to political stalemates.

After this brief overview of twentieth-century history in Panama and Puerto Rico, the paper turns to an examination of both leaders' personal backgrounds and political accomplishments. The main purpose of this exercise is to discover whether or not they contributed to the promotion of some type of democracy in their respective countries. An additional objective is to ascertain whether their personal characteristics contributed to producing certain political effects. We begin with Arnulfo Arias, whose leadership style was more clearly plebiscitarian.

\section{6 'A BETTER PANAMA'}

Arnulfo Arias belonged to a large, middle-class rural family of nine children. ${ }^{7}$ The Panamanian caudillo - the youngest child of Antonio Arias and Carmen Madrid was born on August 15, 1901 in the provincial capital of Penonomé, in whose district his father engaged in cattle ranching. As noted, Panama was then a department (province) of Colombia.

In his hometown, Arias received primary instruction from the Christian Brothers, a French religious order to which Panama's government entrusted the direction of the new republic's educational system. ${ }^{8}$ Encouraged by his mother and supported by his elder brother, Harmodio, who would later become president of the Republic, Arnulfo finished high school at Hartwick College, New York. He later obtained a Bachelor of Science degree from the University of Chicago and culminated his medical studies at Harvard University, where he graduated in 1924. Some observers noted that Arias's training as a physician influenced his approach to politics. One critic, for instance, commented that his background as a surgeon informed his preference for drastic political measures based on the 'surgical knife criterion' (criterio de bisturî) (Escobar 1946, p. 18).

7. The biography of Arias that follows is based on Archivo Nacional de Panamá (1992, p. 163); Benedetti (1963, p. 34); Berguido Guizado (1987); Conte Porras (1990, pp. 27-83); Fábrega and Boyd Galindo (1981, pp. 340-343); Linares (1989, pp. 369-392); Partido Arnulfista (1994); Russo Berguido (1961, pp. 18-22 and 54-63); Sánchez Borbón (2010); and Sepúlveda (1983, p. 8). The paragraphs on Arias's 1940-1941 presidency are taken from Guevara Mann (1996, pp. 61-62).

8. One of the priorities of the country's first government, led by Conservative President Manuel Amador Guerrero (1904-1908), was the organization of a national educational system. Such a system did not exist under Colombian rule (1821-1903) (Céspedes 1985). 
Upon his return to the isthmus in 1926, Arias set up a private medical practice in Panama City and served as a physician in Santo Tomás Hospital, a large, modern public facility. He also taught Hygiene courses at a women's college and gained election as president of the Santo Tomás Medical Society. In 1927 he married into one of Panama's principal families.

His brother Harmodio's successful political career awakened Arnulfo's interest in politics. As a member of the National Assembly in 1924-1928, Harmodio Arias adopted a nationalist stance concerning the country's dependent relationship with the United States. At that time, Arnulfo Arias joined the nationalist society Acción Comunal. Shortly after joining, on January 2, 1931, he led the organization's successful coup d'état against constitutional President Florencio Arosemena, who was widely perceived as having mismanaged the country through the Depression. This experience demonstrated to Arias that in the Panamanian environment, forceful, extra-constitutional means could produce effective political results. The 1931 coup also indicated the need for strong government to maintain power and guarantee order (Escobar 1946, pp. 18, 11, 17, and 24).

Arias's early life experiences, in addition to his naturally impulsive personality, appear to have had some bearing on directing his charisma towards a more plebiscitary style (Conte 1990, p. 114; Escobar 1946, p. 65). During his brother's term as president (1932-1936), he served as chief of the government's Welfare Department and cabinet secretary for Agriculture, Development, and Public Works. As Muñoz Marín would do in 1938, in 1934 Arias founded his own political party, the National Revolutionary Coalition. This party supported the government presidential candidate in 1936, who gained office through electoral fraud.

As a diplomat in Europe (1936-1939) under the ensuing administration, the physicianpolitician undertook graduate study in Gynecology and Obstetrics at the University of Paris and had the opportunity to examine the social security schemes that several Old World countries, notably in Scandinavia, implemented in response to demands for better working conditions. Some critics also add that at this time, Arias - like other Latin American politicians in the 1930s - became attracted to fascism (especially to its Italian variant under Mussolini), including fascist support for strong government (Escobar 1946).

Selected as presidential candidate in the 1940 elections by his National Revolutionary Party ${ }^{9}$ and other organizations supporting the incumbent administration, Arias returned to Panama at the end of 1939. Upon arriving, he proclaimed his Panameñista doctrine, whose motto 'For a Better Panama,' originally coined by Acción Comunal, purported to indicate a commitment to 'the well-being of the Panamanian family through the attainment of improved living, health, and labor conditions' (Partido Arnulfista 1994, p. 1, author's translation). Arias's ideology also advocated 'strengthening Panama's international prestige and position as a politically and economically independent republic among the community of sovereign states' (ibid.). Popular support and government harassment of the opposition candidacy led to his undisputed election to the presidency. The new president assumed office on October 1, 1940.

As chief magistrate, Arias presided over a period of swift and far-reaching reform, aimed at 'awakening the civic conscience from the lethargy' in which it remained (Linares 1989, p. 369, author's translation). The Arias Administration fostered national development and economic redistribution through the creation of a number of government agencies, most saliently the Social Security Administration, considered by many the president's most important achievement; it reorganized the executive and judicial branches; and it promoted what its leader understood as the 'national culture,'

9. The National Revolutionary Coalition became the National Revolutionary Party in 1935. 
deepening among many Panamanians a sentiment of national pride. Last but hardly least, in 1941 Arias enacted a new constitution to replace the republic's original 1904 charter.

The Panameñista statute strengthened presidential powers and, in a typically IbericAmerican reaction to the perceived excesses of Marxism and liberalism, resorted to state intervention in the economy and proclaimed the preponderance of social interest over individual rights. ${ }^{10}$ The 1941 Constitution also withdrew Panamanian nationality from all citizens whose parents belonged to 'races of prohibited immigration,' except for cases in which one of the parents was a Panamanian citizen by birth. These 'races' included non-Spanish-speaking blacks, East Asians, Turks, and North Africans. At the time similar measures existed in other Western Hemisphere countries (including the United States). In Panama, where exclusionary provisions concerning immigration by certain ethnic categories were implemented as early as 1904, the discriminatory elements of the 1941 constitution accentuated the rift between the mainstream mestizo population and the large Afro-Caribbean minority that migrated to the isthmus during canal construction under the United States (1904-1914). ${ }^{11}$

In October 1941, instigated by the United States and with National Police backing, members of his own cabinet removed President Arias from office, securing towards that objective the blessing of Panama's Supreme Court. In his year as chief executive, Arias antagonized important political actors through his efforts at increasing his own personal control over Panamanian politics and in his endeavor to establish a direct, unmediated relationship with the masses, very much in the plebiscitary tradition. The growing independence of Arias's international policy, which countered Washington's interests in the context of World War II, also lost him favor with the Roosevelt Administration. His overthrow was followed by a more compliant Panamanian policy vis-à-vis US interests and, as regards Arias personally, a long period of exile and several months' imprisonment upon his return to the isthmus in 1945. The personal suffering he endured transformed Arias into a victim of the Panamanian establishment and strengthened his heroic reputation, enhancing his charismatic appeal.

In 1948, Arias was once again a presidential candidate on the ticket of his Authentic Revolutionary Party. ${ }^{12}$ Although electoral fraud prevented the Panameñista leader from assuming the presidency in 1948, a political crisis brought about his rise to power the following year, this time with National Police support. Characterized by intense antagonism between the executive and the National Assembly, Arias's rather futile second presidency ended in 1951, shortly after the chief executive attempted to break the deadlock by dissolving the Assembly and replacing the 1946 constitution with his 1941 charter. ${ }^{13}$ To this the chamber responded with a bill of impeachment, served by the National Police after a bloody exchange of gunfire left several people dead and the presidential house in disarray.

10. Stepan $(1978$, ch. 1) sheds light on the 'organic-statist' approach to politics as a typical Iberic-American reaction to both liberalism and Marxism. The similarities between Arnulfo Arias's policies and the organic-statist approach are evident.

11. Szok (2001) provides an interesting interpretation of the tension between the Afro-Caribbean and 'Hispanic' populations in Panama.

12. After his removal from power in 1941, Arias's de facto successor, Ricardo Adolfo de La Guardia, assumed the leadership of the National Revolutionary Party. Following his return from exile, Arias founded the Authentic Revolutionary Party.

13. As noted above, a constituent assembly, elected in 1945, promulgated a new constitution for Panama in 1946. 
Deprived of political rights by the Assembly in May 1951, nine years later Arias was the beneficiary of a political amnesty that allowed him to return to the political scene. He registered a new political base, the Panameñista Party, on whose ticket he ran for office a third time, in 1964. Fraud forestalled his rise to power on that occasion, but in 1968 he was able to capitalize on a split in the ruling Liberal party and secure his election to the presidency. This time he was driven out by the National Guard after only eleven days in office. His overthrow resulted in a decade-long exile in Miami until the military dictatorship allowed his return in $1978 .{ }^{14}$

Back in Panama, taking advantage of a new electoral law passed by the military regime, Arias registered his Authentic Panameñista Party in $1983 .{ }^{15}$ As in the case of Luis Muñoz Marín, Arias's energetic concern for establishing political parties contrasts with Weber's observations about the pure charismatic type, whose mission, according Weber, does not normally rely on parties for implementation, but may become bureaucratized in party organizations after the leader's disappearance. With Arias at its helm, despite the leader's old age and frailty, the Authentic Panameñista Party became the cornerstone of opposition to the military dictatorship in the 1984 electoral process. But fraud once more frustrated Arnulfo Arias's fifth and last bid for the country's highest office, as candidate of a coalition opposing the US-supported military regime.

Throughout the military period, but especially from his return from exile in 1978 to his death a decade later, Arias served as a unifying symbol against the dictatorship. When he died, in August 1988, the largest multitude Panama had ever seen showed up for his funeral (Koster and Sánchez Borbón 1990, p. 361). Despite predictions that Panameñismo would descend to the grave with its founder, the party remained an important participant in the country's politics during and after the transition to liberal democracy in 1989-1994. Panameñista Presidents Guillermo Endara and Arias's widow, Mireya Moscoso, governed the isthmus in 1989-1994 and 1999-2004, respectively. Though in 2009 the party gave up its own presidential candidacy to support the aspirations of President Ricardo Martinelli (2009-2014), it contributed a significant number of votes and elected officials to the coalition government led by Martinelli. In 2014, Panameñista presidential nominee Juan Carlos Varela won the republic's main office.

\section{7 'BREAD, LAND, AND LIBERTY'}

El Vate, or 'The Bard,' as supporters called Luis Muñoz Marín on account of his poetical inclinations, was born in San Juan, the capital of Puerto Rico, on February 18, 1898. ${ }^{16}$ He was the son of Luis Muñoz Rivera, a leading politician of the island, who at the time of his son's birth was secretary of Justice and Government in the autonomous regime that the Spanish crown instituted in Puerto Rico shortly before the Spanish-American War. After the establishment of US military government, Muñoz Rivera and his family moved to New York, where the senior Muñoz worked as the editor of a newspaper

14. As noted above, the military regime lasted from 1968 to 1989 under military leaders Omar Torrijos (1968-1981), Rubén Paredes (1982-1983), and Manuel Noriega (1983-1989).

15. Early in 1983, two former Arias supporters, backed by the military regime, appropriated the traditional label and symbols of the Panameñista Party.

16. The biography of Muñoz Marín that follows is based on Anderson (1965, p. 49); Mathews (1960, pp. 3 and 288-296); Mathews (1967, pp. 7-59); Muñoz Marín (1985, pp. 74-85 and 124); and Quintero Rivera (1986). 
focused on Puerto Rican affairs. Returning to the island in 1906, he once more became involved in local politics. In 1910 he was elected resident commissioner (that is, representative without vote) to the US House of Representatives, a position Muñoz Rivera filled until his death in 1916.

Luis Muñoz Marín grew up in a family sensitive to cultural and political issues, attached to urban, cosmopolitan, middle-class, liberal values, and these familial traits doubtless shaped his proclivity towards art and culture as well as his incursions into poetry and writing. He received a secular education in San Juan and New York and completed high school at Georgetown University's preparatory school. Between 1915 and 1916 at Georgetown he concluded the first year of the Law course and during the 1916-1917 academic term he studied Journalism at Columbia University. His period in the United States and his educational experiences there provided Muñoz Marín with a profound understanding of US idiosyncrasies, which later proved a substantial asset for his political career.

In addition to upbringing and the example of his father - whose highly successful public involvement inspired, in part, his son's participation in politics - Muñoz Marín's early civic engagement was an important factor in awakening his political ambitions. The younger Muñoz, a regular contributor and at times editor of Puerto Rican newspapers such as La Democracia, the Liberal Party organ and La Revista de Indias, served as secretary to the Puerto Rican resident commissioner in Washington, DC between 1917 and 1919. A concern for the situation of his country's workers led to collaboration with the pro-US, pro-labor Puerto Rican Socialist Party during the 1920 legislative campaign. In 1932 he was elected to the island's Senate on the Liberal (formerly Union) Party ticket and during this first term as elected officer he participated, along with Roosevelt Administration officials, in the design of the Puerto Rican Reconstruction Administration, an economic development scheme conceived to improve the depressed economic conditions of the island. As an advocate of this project he actively promoted it in Washington and, on the island, 'he was its leading spokesman' (Mathews 1967, pp. 17-20 and 27-28).

During his first senatorial term (1933-1937), Muñoz Marín developed an anticorporationist stance. He gradually came to regard control of the Puerto Rican factors of production (mostly cane plantations and sugar mills) by private US corporations as accentuating the poverty of the island's masses and, as such, detrimental to the interests of Puerto Rico. Certainly, according to historical assessments, increased concentration of agricultural land and other resources - one of the main consequences of Washington's annexation of the island - had dislocating effects on Puerto Rican society in the early twentieth century (Quintero Rivera 1986). At this time he also fully concurred with the position of his Liberal Party, which stood for Puerto Rican independence. But when in 1936, in response to nationalist agitation in Puerto Rico, an independence bill was introduced in the US Congress, the senator modified his stance, arguing that severing links with the United States - without any promise of economic assistance - would spell ruin for his country. The ideological adjustment to 'independence with economic justice' led to collision with the leaders of the Liberal Party, which expelled him in 1937 (Bayrón Toro 2003, p. 192).

Eviction from the Liberal Party helped cast Muñoz Marín in the role of a victimized, selfless politician, an image oftentimes associated with charismatic leadership. Contrary to Weber's prediction that the charismatic mission is normally institutionalized after the leader's disappearance, El Vate seized on the opportunity this expulsion awarded to establish his own political base. In 1938 he founded the Popular Democratic Party (Partido Popular Democrático or PPD), whose agenda focused on improving the conditions 
of the underprivileged, especially the jíbaros, the colloquial denomination for Puerto Rican farmers. Consistent with its founder's thought, the PPD platform gave the introduction of social legislation priority over independence. Muñoz Marín then devoted most of the 1938-1940 biennium to carrying out an innovative campaign that appealed to and related directly with the common man, especially the jíbaro (traditional farmer), who became the symbol of the PPD, alongside the party slogan, 'Bread, Land, and Liberty.' After two years of intense proselytizing, the PPD won a plurality in the 1940 senatorial elections and Muñoz Marín became president of the upper chamber of the island's legislature. Charisma and the organizational resources of the PPD made him Puerto Rico's foremost political figure, a position Muñoz Marín would retain for some three decades.

From the island's Senate (to which he was re-elected in 1944), El Vate promoted the enforcement of a law limiting the size of landholdings as well as distributing land to property-less peasants. Under his leadership, the PPD also introduced bills designed to supply the poor with basic services such as drinking water and electricity, medical care, and school meals. Implementation of these measures boosted the popularity of the PPD and the prestige of its chief, which became more evident in 1944, when the party won all but two seats in the Puerto Rican House and Senate. Concurrently, by concentrating on the solution of socio-economic problems and avoiding, during the critical years of World War II, a definition of Puerto Rico's political status, Muñoz Marín assured the collaboration of the United States in instituting measures to redistribute wealth to the island's underprivileged.

To some extent, Washington's respect for what from a US perspective was El Vate's responsible politics accelerated a settlement of the Puerto Rican nationality problem. In 1946 the Truman Administration appointed the first Puerto Rican national - Jesús Piñero, a close ally of Muñoz Marín - as governor. Free elections to that office took place in 1948, with the PPD leader as victor. As Puerto Rico's first elected governor, Muñoz Marín now saw it fit to promote a status change. His own pragmatism informed the choice of a 'commonwealth' over statehood (which entailed payment of federal income taxes) or independence (which implied giving up free access to the US market). While in effect assuring self-government, commonwealth status also seemed to Muñoz Marín and his supporters to provide Puerto Rico with a distinct identity in the international arena, an issue to which the PPD and its leader were sensitive.

The Commonwealth of Puerto Rico, Muñoz Marín's crowning achievement, was adopted through the Constitution of 1952, proclaimed after approval by the US Congress and the island's electorate. That year also marked the election of the PPD leader to a second term as governor, a position to which he would gain re-election in 1956 and 1960. During his tenure as the island's chief executive, Muñoz Marín mostly focused on economic development. 'Operation Bootstrap,' an industrialization scheme funded by federal taxes on Puerto Rican rum sold in the United States, was perhaps his best-known endeavor in this regard. While the prospects of cheap labor and free entry into the continental market prompted many US enterprises to establish factories on the island, thus increasing job supply, opponents accused Muñoz Marín of retreating from his previous, nationalist stance and placing Puerto Rico's resources at the service of US corporations.

Yet while economic development represented one of the PPD's main concerns, Muñoz Marín and his party also expressed interest in securing the cultural bases of Puerto Rican society. Such organizations as the Institute of Puerto Rican Culture (1955) and others - which Muñoz Marín founded - purported to 'preserve the fast disappearing characteristics' of traditional Puerto Rican life and strengthen the cultural 
identity of the island's people (Mathews 1967, pp. 53-54). These entities, as well as the economic development initiatives, and, above all, the 1952 Constitution and commonwealth arrangement with the United States, represent the legacy of Muñoz Marín, an able, successful, and charismatic politician who left an indelible mark on Puerto Rican politics through over 30 years of public service and was the island's towering politician until his death in $1980 .{ }^{17}$ Significantly, the PPD has remained an important political actor on the island since Muñoz Marín's retirement in 1969. PPD candidates won election as governor of Puerto Rico in 1964 (Roberto Sánchez Vilella), 1972 (Rafael Hernández Colón), 1984 (Rafael Hernández Colón), 1988 (Rafael Hernández Colón), 2000 (Sila María Calderón), 2004 (Aníbal Acevedo Vilá), and 2012 (current Governor Alejandro García Padilla) (Commonwealth Elections Commission of Puerto Rico 2015).

\section{IDENTIFYING POLITICAL CHARISMA}

How can we ascertain that Arias and Muñoz Marín were charismatic leaders? Measuring charisma is, indeed, a daunting task. One way of establishing the charismatic mission is through a scrutiny of the paper trail documenting a leader's career. In the case of Arnulfo Arias, there is near unanimity regarding his charismatic qualities. A study of Panamanian society at mid twentieth century described as Arias's 'most notable attribute' the attraction of his 'flamboyant personality and ardent nationalism' (Biesanz and Biesanz 1956, p. 140). 'His greatest asset was himself,' agree the authors of a political history of Panama, who note Arias's vigorous, magnetic character and his ability to transform 'disparate individuals into a cohesive, frenzied crowd' (Koster and Sánchez Borbón 1990, p. 60). Arias's discourse 'electrified' his supporters and his personal boldness was taken as an evident sign of superiority (ibid.).

'No other figure in Panamanian history so deeply stirred the emotions of his fellow countrymen,' wrote Robinson (1999, p. 157). His appeal stemmed partly from a powerful, captivating demeanor and partly from a controversial career that provided him with the aura of a martyr and the reputation of a hero, together with a capacity to represent the ideals of the isthmus' urban and, especially, rural masses (Conte Porras 1990, p. 111). These characterizations relate to the exemplary, gifted, and heroic nature of charismatic leadership, according to Weber (1922 [1978], pp. 241 and 215). While there are several assessments of Arias's career - both favorable and unfavorable - few, if any, deny the charismatic component of his leadership.

Appraisals of Luis Muñoz Marín's career also emphasize the charismatic basis of his political success. A collection of Hispanic American politicians' biographies refers to him as 'Puerto Rico's charismatic and immensely popular governor' (Wasniewski 2013, p. 458). According to The New York Times, Muñoz Marín was a 'charismatic figure' who ruled Puerto Rico 'by fiat' (Thomas 1997).

Even a strong critic of traditional Puerto Rican politics underscores the former governor's 'personal charisma' (Staudenmaier 2003). In a review of a book on leadership in the Caribbean, Mario Fenyo (2004), however, refers to the 'relatively weak charisma of Muñoz Marín.’ But Thomas P.F. Hoving, director of New York City's Metropolitan Museum of Art, wrote: 'The man with the most charisma I ever saw is Muñoz Marín

17. As noted above, Muñoz Marín held public office for 32 years, serving four terms as senator (1933-1937, 1941-1945, 1945-1949, 1965-1969) and four terms as governor (1949-1953, 1953-1957, 1957-1961, 1961-1965). 
of Puerto Rico. The moment he walks into the room, you feel it whether you know who he is or not.' 18

Political scientist Robert W. Anderson alluded to Muñoz Marín's 'immense power and prestige,' underscoring the strong devotion he generated in supporters, a feature recognized in the portrayal of charismatic leadership by Weber (1922 [1978], pp. 215, 269, and 1112):

His followers have likened him to the Son of God Himself. He has been referred to as the 'caudillo chosen by God to lead his people.' He has been called 'a man of absolute impartiality, of intellectual integrity and honesty, who would never in his official capacity act arbitrarily, abusively, or unfairly toward any minority group.' Indeed, the paeans of praise to his virtue are matched in passion only by the vitriolic damnation of his opponents. (Anderson 1965, pp. 78-79)

Because electoral performance might indicate the popularity of a political leader at a moment in history, it might as well contribute indirectly to illustrate the charismatic appeal of a politician. ${ }^{19}$ While not all electorally successful politicians are charismatic, and though not all charismatic leaders operating in an electoral environment are successful at the ballot box, some relationship between success in elections and charismatic leadership might be reasonably expected. Arnulfo Arias rose to Panama's presidency three times $(1940,1949,1968)$ as a result of a popular vote ${ }^{20}$ electoral fraud prevented him from assuming his country's principal office in 1964 and 1984. While pervasive electoral manipulation renders official election results in Panama an unreliable statistic, they are somewhat indicative of the degree of support enjoyed by Arias at the polls. According to official records, in four of the five presidential elections in which he ran as a candidate, Arias obtained the proportions of the popular vote shown in Table 2.

Muñoz Marín won eight elections, four for senator to the island's upper chamber (1932, 1940, 1944, 1964) and four for governor of Puerto Rico (1948, 1952, 1956, 1960). In the gubernatorial elections in which he ran as a candidate, Muñoz Marín obtained the proportions of the popular vote shown in Table 3.

In sum, while the literature normally refers to both politicians as charismatic leaders in a Weberian sense, highlighting the 'exceptional' and 'extraordinary' elements of their leadership as recognized by their followers, a biographical review indicates that the charismatic component was perhaps stronger in Arias than in Muñoz Marín. Both were successful at the ballot box, though Muñoz Marín won more elections

18. Quoted by New York Times columnist Frank Safire, in turn quoted by Maldonado (2006, p. 9).

19. Maria Hsia Chang and Derek Kauneckis emphasized the importance of this indicator.

20. In 1940, Arias was the government's unopposed candidate. The opposition standardbearer, former caretaker President Ricardo J. Alfaro (1931-1932), withdrew his candidacy on account of the administration's maltreatment. In the fraudulent 1948 elections, Arias was denied victory. When a political crisis demanding the resignation of the police chiefs erupted a year later, Commandant José Antonio Remón, the country's de facto ruler, ordered a 'recount' of the ballots which resulted in a correction of the electoral results in favor of Arnulfo Arias. Arias then ascended to the presidency for a second time (Berguido Guizado 1987; Pippin 1964). After the National Guard recognized his victory in the May 1968 elections, Arias manipulated the results of elections to the National Assembly and the main municipal councils to create majorities in his favor. Additionally, after agreeing to replace National Guard chiefs in accordance with the organization's hierarchy (a sensitive issue for the military), once he assumed office Arias began implementing a major overhaul of the security force. These measures increased polarization among the country's main political actors, leading to the coup of October 11, 1968 (Guevara Mann 1996). 
110 Leadership and the Humanities, Vol. 3 No. 2

Table 2 Proportion of popular vote obtained by Arnulfo Arias in presidential elections, Panama, 1940-1984

\begin{tabular}{lc}
\hline Year & Percentage \\
\hline 1948 & $36 \%$ \\
1964 & $38 \%$ \\
1968 & $55 \%$ \\
1984 & $47 \%$ \\
\hline
\end{tabular}

Source: Nohlen (1993, pp. 491-494). In his compilation, Nohlen does not report figures for the 1940 election. He also notes the 'unreliable' character of results in 1948.

Table 3 Proportion of the popular vote obtained by Luis Muñoz Marín in gubernatorial elections, Puerto Rico, $1948-1960$

\begin{tabular}{lc}
\hline Year & Percentage \\
\hline 1948 & $61 \%$ \\
1952 & $65 \%$ \\
1956 & $63 \%$ \\
1960 & $58 \%$ \\
\hline
\end{tabular}

Source: Commonwealth Elections Commission of Puerto Rico (2015).

than Arnulfo Arias. Perhaps this was in part a reflection of the constraints of Panama's electoral system and the instability of its politics, and in part a reflection of the different paths along which both leaders pursued political office. ${ }^{21}$ The record points to stronger performance by Muñoz Marín in elections to executive office, though statistics for Panama are suspect on account of a robust tradition of fraud and manipulation.

Yet another helpful indicator would be the size of each leader's following relative to their countries' electorate. This could be determined by quantifying the membership in each leader's political party, but results would necessarily require qualification owing to incomplete records and irregularities in registration procedures. Furthermore, the relevant statistics are not readily available.

\section{POLITICAL CHARISMA, CONSTITUTIONAL LEGACIES, AND DEMOCRACY}

The preceding section established the charismatic quality of Muñoz Marín's and Arias's leadership, at least according to the testimonies of political observers. It also showed their popularity as leaders, based on the available electoral record. The

21. From the perspective of representative democracy, Muñoz Marín's career followed a more traditional, progressive path, beginning with election to the Puerto Rican Senate and continuing with popular selection to the island's governorship. Arias's career began with a coup d'état, followed by appointive office, after which he was nearly unanimously elected to the presidency, in an uncontested vote. Subsequently, he gained two re-elections. On all three occasions his administration concluded early, through forceful removal prior to the end of the term. 
paper proceeds with an examination of the constitutions both leaders promoted in their respective countries. These constitutions were not solely the product of Arias's and Muñoz Marín's leadership. Other factors intervened, especially in Puerto Rico, which is even more closely associated with the United States than Panama. Puerto Rican delegates to the 1951-1952 Constituent Convention were not likely to approve measures that severely contradicted US interests. However, following Dahl (1989, p. 261), it is safe to say that leaders' preferences influenced the constitutional texts adopted during their tenure (perhaps more in Arias's case).

This paper argues that charismatic leadership helped promote plebiscitary democracy in Panama and representative democracy in Puerto Rico. Analysis of the constitutional legacies of Arnulfo Arias and Luis Muñoz Marín supports this assertion. Both charismatic leaders exhibited a concern for establishing a new political order in their countries. This concern translated into the promulgation of Panama's constitution of 1941 and Puerto Rico's charter of 1952..22

Both statutes prescribed a republican and representative form of government, the distribution of power among three branches, and a bill of rights. On closer scrutiny, however, Muñoz Marín's constitution met the standards of liberal democracy better than Arias's charter. In Panama, the exclusionary provisions of the 1941 constitution, based on ethnic considerations, contradicted the democratic requirement of inclusive suffrage. In line with the Latin American constitutional tradition, it also defined basic political freedoms in more restricted fashion.

For example, following the First Amendment to the US Constitution, Article II, Section 4 of the Puerto Rican charter stipulates that "[n]o law shall be made abridging the freedom of speech or of the press, or the right of the people peaceably to assemble.' Article 39 of Panama's 1941 Constitution guaranteed freedom of expression as long as opinions did not attack the honor of other individuals or threaten 'social security or public tranquility.' Article 41 secured the right to assembly, but required that local authorities receive prior notice of public gatherings and contemplated the adoption of police measures 'to prevent or repress abuses in the exercise of this right when it causes or might cause an alteration of public order or the violation of third party rights.' In this and other regards, the 1941 Constitution in Panama was less liberal than the 1952 statute in Puerto Rico.

The Panameñista charter of 1941 strengthened the executive branch, most notably through an increase in the presidential term from four to six years and an expanded role for the government in economic matters. Although the terms of the National Assembly deputies also increased to six years, the chamber's participation in the conduct of public affairs essentially remained limited to endorsing the president's initiatives, as under the preceding Constitution of 1904. Furthermore, the 1941 charter introduced a provision whereby the Assembly could delegate legislative authority to the executive for specific purposes (Article 88, Section 20). This clause, which did not exist in the 1904 Constitution, has remained a feature of Panama's constitutionalism ever since, even after the charter of 1946 replaced the statute of 1941. As such, it is an important (albeit controversial) contribution of plebiscitarianism to Panama's constitutional tradition. ${ }^{23}$ No similar provision exists in the Puerto Rican Constitution.

22. For the text of both constitutions, see Fábrega and Boyd Galindo (1981) and Commonwealth of Puerto Rico (1952).

23. The executive's recourse to 'extraordinary powers' has elicited much criticism and controversy from advocates of representative democracy in recent years. For contemporary critiques of these measures, see El Panamá América (1998), Rosas (2006), and Zúñiga (2006). 
Strengthening the executive branch was consistent with Arias's 'plebiscitary' or 'delegative' notion of democracy, which holds a view of the elected president as 'the embodiment of the nation and the main custodian and definer of its interests' (O'Donnell 1994, p. 60). In the plebiscitary model, as the nation's representative, the chief magistrate's exercise of power remains as unconstrained as possible by other branches of government. Contrariwise, Muñoz Marín's constitution of 1952 maintained the traditional, four-year term of office and limitations on the executive branch characteristic of the US constitution, together with a more balanced distribution of power. ${ }^{24}$

Shugart and Carey (1992, pp. 148-158) provide a more systematic measure of executive power that, as argued above, might be taken as a useful indicator of the plebiscitary or liberal tendencies in a regime. The authors classify executive powers in two dimensions: legislative and non-legislative. In the first dimension they include the package veto, the partial veto, decree power, exclusive introduction of legislation, budgetary initiative, and the ability to propose referenda. Their non-legislative powers include cabinet formation, cabinet dismissal, censure, and dissolution of the assembly. For each item, Shugart and Carey rank presidential systems from 0 (no executive power) to 4 (strongest executive power). Their total scores range from a weak 4 (Romania, 1991) to a strong 24 (Chile, 1969).

Following Shugart and Carey, the present paper measures the constitutional powers of the Panamanian and Puerto Rican executives according to the 1941 and 1952 Constitutions. For comparative purposes, the exercise includes Shugart and Carey's scores for the US Constitution of 1787, which served as a model for the Puerto Rican charter. It also includes Panama's 1904 Constitution, the predecessor of Arnulfo Arias's statute, to determine whether the 1941 Constitution provided for a stronger executive than its forerunner (it did, albeit slightly). Although, as Shugart and Carey emphasize,

Table 4 Constitutional powers of popularly elected executives in the United States, Panama, and Puerto Rico (1787, 1904, 1941, and 1952 Constitutions)

\begin{tabular}{lcccc}
\hline & \multicolumn{4}{c}{ Constitution } \\
\cline { 2 - 5 } Powers & $\begin{array}{c}\text { United States } \\
(1787)\end{array}$ & $\begin{array}{c}\text { Panama } \\
(1904)\end{array}$ & $\begin{array}{c}\text { Panama } \\
(1941)\end{array}$ & $\begin{array}{c}\text { Puerto Rico } \\
(1952)\end{array}$ \\
\hline Legislative powers & 2 & 1.5 & 2 & 2 \\
Package veto & 0 & 3 & 3.5 & 0 \\
Partial veto & 0 & 0 & 0 & 0 \\
Decree & 0 & 0 & 0 & 0 \\
Exclusive introduction & 0 & 0.5 & 0.5 & 0 \\
Budgetary initiative & 0 & 0 & 0 & 0 \\
Referendum & 3 & 4 & 4 & 3 \\
Non-legislative powers & 4 & 4 & 4 & 4 \\
Cabinet formation & 4 & 4 & 4 & 4 \\
Cabinet dismissal & 0 & 0 & 0 & 0 \\
Censure & 13 & 17 & 18 & 13 \\
Dissolution & & & & \\
Total & & & & \\
\hline
\end{tabular}

Source: Adapted from Shugart and Carey (1992, pp. 148-158).

24. In another important respect, however, while the 1941 Constitution ruled out immediate reelection by the president, Puerto Rican electoral law allowed the governor to run for re-election without any limits. Limitations on re-election are an important constraint on the powers of the executive, especially where those powers are broad, such as in the Latin American republics. 
this method of assessing executive power is by no means exhaustive, the results of the exercise are helpful and quite revealing, as shown in Table 4.

According to this assessment, the US Constitution of 1787 and the Puerto Rican Constitution of 1952 provide the less vigorous executives, which, as a result, are more subject to horizontal accountability than the two Panamanian cases. The US and Puerto Rican Constitutions grant the executive a 'package' veto that may be overridden by two-thirds of each of the two houses of the legislative branch. Thus the moderate score (2 out of a possible 4 ) referring to this indicator. US and Puerto Rican executives do not have partial veto, decree, exclusive introduction, budgetary, or referendum powers; as a result, they score 0 on all these counts. As cabinet appointments require Senate confirmation, the 1787 and 1952 Constitutions receive 3 out of 4 points for 'cabinet formation.' The executive may dismiss cabinet secretaries at will and the legislature cannot issue votes of censure against these secretaries; thus the score of 4 in each of these categories. Because the executive may not dissolve the Congress, the score here is 0 for both the United States and Puerto Rico.

Panama's Constitutions of 1904 and 1941 provide for a significantly stronger executive, associated with weaker horizontal accountability. Both charters contained the line item veto, gave budgetary initiative to the president, and allowed him to appoint his cabinet without Assembly approval. Arnulfo Arias strengthened the Panamanian president's legislative powers by stipulating that executive vetoes could only be overridden (as in the US and Puerto Rican constitutions) 'by two-thirds of the deputies comprising the Assembly' (Article 97). Previously, according to Article 105 of the 1904 Constitution, presidential vetoes could be overridden by two-thirds of the quorum. Overall, the Panamanian 1941 Constitution scores 18 points, compared to the Puerto Rican Constitution's 13 points.

The obvious conclusion derived from this exercise is that Arnulfo Arias's charismatic leadership favored an even more autonomous presidency than previously, less subject to the horizontal controls of representative democracy. Luis Muñoz Marín, the promoter of Puerto Rico's 1952 statute, preferred a more balanced power-sharing arrangement, closely following the representative model of US democracy. A more powerful executive fits well with a plebiscitary notion of democracy, while a more balanced power-sharing arrangement conforms to the notions of horizontal accountability inherent in representative democracy. In the Caribbean Basin countries studied here, charismatic leadership contributed to produce these two different results.

\section{CONCLUSION}

In its pure form, charismatic leadership is irrational (that is, not subject to legal-rational procedures), informal, arbitrary, and personalistic. It seems to have little in common with modernity or the democratic system, which derives its legitimacy from a legal-rational source. Charismatic leadership, however, may arise in modern societies and generate important transformations. It may trigger regime changes, including the inauguration, reinstatement, or institutionalization of some form of democracy.

Plebiscitary or delegative democracy is the democratic type most readily associated with a charismatic mission. Plebiscitary democracy emphasizes elections - that is, vertical accountability - as a means of legitimizing the leader's authority. This emphasis on the link between the ruler and the ruled, together with a dismissal of horizontal controls exemplified by Arnulfo Arias's career in Panama - may undermine prospects for the fulfillment of representative democracy. In this regard, as posited by O'Donnell (1994, p. 60), plebiscitary democracy is 'less liberal' than its representative cousin. 
A reading of recent Puerto Rican history, however, shows that charismatic leadership and representative democracy are not necessarily antagonistic. Charismatic leadership may help institutionalize representative democracy if the charismatic leader is motivated by liberal democratic values and if a foreign dominant power (such as the United States) places limits on the 'delegative' behavior that politicians might incur. This possibility is exemplified by the career of Luis Muñoz Marín in Puerto Rico between 1933 and 1969.

Representative democracy is a more democratic form than plebiscitary democracy, because it ensures that representatives are held accountable both vertically (by voters, at periodic elections) and horizontally (between elections, by constitutional agencies of control). If charismatic leadership contributes to institutionalize representative democracy, as Muñoz Marín did in Puerto Rico, such a contribution is likely to represent progress along the road to a democratic ideal. When charismatic leadership contributes to promote plebiscitarianism, issuing a value judgment is more complex.

Plebiscitary democracy might constitute an improvement if the preceding regime is even less democratic or non-democratic. But charismatic leadership, which Weber defined as 'the great revolutionary force' (1922 [1978], p. 245), may also contribute to the breakdown of representative democracy and, as a result, to a regression to less developed forms of democracy or outright non-democracy. This happened in Panama, where the plebiscitarian traits of Arias's charismatic leadership (together with other structural and geopolitical factors) helped escalate tensions leading to de facto rule in 1941-1945, National Police meddling in politics in 1947-1955, and military dictatorship in 1968-1989.

Contrariwise, over the long military period, Arias's charismatic leadership became the emblem of civilian and constitutional rule against a repressive and venal military regime. Certainly, as shown by Polity IV scores for Panama (Table 1), his leadership was more democratic (or less undemocratic) than rule by Panama's military. As a leader of the opposition and presidential candidate in 1984, Arias became a living symbol of the 'civilist' cause on the isthmus. In this way, despite old age, Arias contributed to keep the yearning for democracy alive in Panama during a non-democratic epoch. This was, perhaps, the greatest service he provided his country.

\section{NOTES}

Earlier versions of this paper were presented at a Department of Political Science colloquium at the University of Nevada, Reno, January 2006; the XXVI International Congress of the Latin American Studies Association (LASA), San Juan, Puerto Rico, March 15-19, 2006; the Second National Meeting of Political Scientists, Panama, June 16-17, 2006; and the conference on 'Democracy and Participation in Latin America,' University of Sussex, March 19-21, 2015. For valuable comments and suggestions I am grateful to Betty Brannan Jaén, Maria Hsia Chang, Robert Fishman, Brittmarie Janson Pérez, Derek Kauneckis, John Marini, Aníbal Pérez Liñán, Gloria Rudolf, and two anonymous reviewers for Leadership and the Humanities. Mihaela Neagos assisted in compiling data.

\section{REFERENCES}

Anderson, Robert W. 1965. Party Politics in Puerto Rico. Stanford, CA: Stanford University Press.

Archivo Nacional de Panamá. 1992. La modernización del Estado Panameño bajo las administraciones de Belisario Porras y Arnulfo Arias Madrid. Panama: Instituto Nacional de Cultura. 
Bayrón Toro, Fernando. 2003. Elecciones y partidos políticos de Puerto Rico: 1809-2000. Mayagüez: Editorial Isla.

Benedetti, Adolfo Alberto. 1963. Arnulfo Arias, el caudillo. Panama: Editora Humanidad.

Berguido Guizado, Fernando. 1987. La sucesión presidencial en el derecho panameño. Panama: Editorial La Antigua.

Biesanz, John and Biesanz, Mavis. 1956. The People of Panama. New York: Columbia University Press.

Bobbio, Norberto. 1987. The Future of Democracy: A Defence of the Rules of the Game. Translated by Robert Griffin. Edited and introduced by Richard Bellamy. Minneapolis: University of Minnesota Press.

Céspedes, Francisco. 1985. La educación en Panamá: panorama histórico y antología. 2nd edn. Panama: Editorial Universitaria.

Commonwealth Elections Commission of Puerto Rico. 2015. 'Elections in Puerto Rico.' Available at: http://electionspuertorico.org, accessed April 3, 2015.

Commonwealth of Puerto Rico. 1952. Constitution of the Commonwealth of Puerto Rico. Available at: http://senado.pr.gov/SiteCollectionDocuments/The\%20Constitution\%20of\%20the\% 20Commonwealth\%20of\%20Puerto\%20Rico.pdf, accessed March 10, 2015.

Conte Porras, Jorge. 1990. Réquiem por la revolución, San José: Litografía e Imprenta Lil.

Dahl, Robert. 1971. Polyarchy: Participation and Opposition. New Haven, CT: Yale University Press.

Dahl, Robert. 1989. Democracy and its Critics. New Haven, CT: Yale University Press.

Diamond, Larry and Morlino, Leonardo. 2005. 'Introduction.' In Assessing the Quality of Democracy, edited by Larry Diamond and Leonardo Morlino. Baltimore, MD: The Johns Hopkins University Press, pp. ix-xliii.

El Panamá América. 1998. 'Facultades extraordinarias' (editorial). January 18.

Escobar, Felipe Juan. 1946. Arnulfo Arias o el credo panameñista: ensayo psico-patológico de la política panameña. Panama: self-published.

Fábrega, Ramón and Boyd Galindo, Mario, eds. 1981. Constituciones de la República de Panamá: 1972, 1946, 1941, 1904. Panamá: Centro de Impresión Educativa.

Fenyo, Mario D. 2004. 'Review of Caribbean Charisma: Reflections on Leadership, Legitimacy and Populist Politics.' Journal of Third World Studies, 21(1): 316.

Fox, Jonathan. 2000. 'Civil Society and Political Accountability: Propositions for Discussion.' Paper presented at the conference on 'Institutions, Accountability and Democratic Governance in Latin America,' The Helen Kellogg Institute for International Studies, University of Notre Dame, May 8-9.

Guevara Mann, Carlos. 1996. Panamanian Militarism: A Historical Interpretation. Athens: Ohio University Center for International Studies.

Huntington, Samuel. 1968. Political Order in Changing Societies. New Haven, CT: Yale University Press.

Judge, David. 1999. Representation: Theory and Practice in Britain. London and New York: Routledge.

Koster, Richard M. and Sánchez Borbón, Guillermo. 1990. In the Time of the Tyrants: Panama, 1968-1990. New York: W.W. Norton.

La Torre, Carlos de. 2013. 'El tecnopopulismo de Rafael Correa.' Latin American Research Review, 48(1): 24-43.

Linares, Julio E. 1989. Enrique Linares en la historia política de Panamá, 1869-1949. San José: Litografía e Imprenta Lil.

Linz, Juan José. 1978. The Breakdown of Democratic Regimes: Crisis, Breakdown, and Reequilibration, Baltimore, MD and London: The Johns Hopkins University Press.

Maldonado, A.W. 2006. Luis Muñoz Marín: Puerto Rico's Democratic Revolution. San Juan: Universidad de Puerto Rico.

Marshall, Monty G., Gurr, Ted Robert, and Jaggers, Keith. 2014. 'Polity IV Project, Political Regime Characteristics and Transitions, 1800-2013.' Vienna, PA: Center for Systemic Peace. Available at: http://www.systemicpeace.org/inscrdata.html, accessed March 10, 2015. 
Mathews, Thomas. 1960. Puerto Rican Politics and the New Deal. Gainesville, FL: University of Florida Press.

Mathews, Thomas. 1967. Luis Muñoz Marín: A Concise Biography. New York: American RDM Corporation.

Morris, Nancy. 1995. Puerto Rico: Culture, Politics, and Identity. Westport, CT: Praeger.

Muñoz Marín, Luis. 1985. Historia del partido popular democrático. San Juan: Editorial Batey.

Nohlen, Dieter. 1993. Enciclopedia electoral Latinoamericana y del Caribe. San José: Instituto Interamericano de Derechos Humanos.

O'Donnell, Guillermo. 1994. 'Delegative Democracy.' Journal of Democracy, 5(1), 55-69.

O’Donnell, Guillermo. 1996. 'Illusions About Consolidation.' Journal of Democracy, 7(2): 34-51.

Panebianco, Angelo. 1988. Political Parties: Organization and Power. Cambridge, UK: Cambridge University Press.

Partido Arnulfista. 1994. Declaración de principios y programa de gobierno. Panama: Partido Arnulfista.

Pippin, Larry LaRae. 1964. The Remón Era: An Analysis of a Decade of Events in Panama, 1947-1957. Stanford, CA: Institute of Hispanic American and Luso-Brazilian Studies, Stanford University.

Quintero Rivera, Ángel. 1986. 'Puerto Rico, c. 1870-1940.' In The Cambridge History of Latin America, Volume 5, 'c.1870 to 1930,' Part II, 'Central America and the Caribbean,' edited by Leslie Bethell. Cambridge, UK: Cambridge University Press, pp. 265-286.

Robinson, William Francis. 1999. 'Panama for the Panamanians: The Populism of Arnulfo Arias Madrid.' In Populism in Latin America, edited by Michael L. Conniff. Tuscaloosa and London: University of Alabama Press.

Rosas, Jorge Rubén. 2006. 'Concesión de facultades extraordinarias.' La Prensa, February 16. Available at: http://mensual.prensa.com/mensual/contenido/2006/02/16/hoy/opinion/503262. html, accessed March 10, 2015.

Russo Berguido, Alessandro. 1961. Horario de una traición (10 de Mayo de 1951). Panama: selfpublished.

Sánchez Borbón, Guillermo. 2010. 'Sobre constituciones y golpes.' La Prensa, June 18. Available at: http://mensual.prensa.com/mensual/contenido/2010/06/18/hoy/opinion/2229210.asp, accessed March 10, 2015.

Sepúlveda, Mélida Ruth. 1983. Harmodio Arias Madrid: El hombre, el estadista y el periodista. Panama: Editorial Universitaria.

Shugart, Matthew Soberg and Carey, John M. 1992. Presidents and Assemblies: Constitutional Design and Electoral Dynamics. Cambridge, UK: Cambridge University Press.

Staudenmeier, Mike. 2003. 'National Struggle and Class Struggle in Puerto Rico: Lessons for Anarchists.' Common Struggle, June 26. Available at: http://commonstruggle.org/node/ 500, accessed March 10, 2015.

Stepan, Alfred. 1978. The State and Society: Peru in Comparative Perspective. Princeton, NJ: Princeton University Press.

Szok, Peter. 2001. 'La última gaviota': Liberalism and Nostalgia in Early Twentieth-Century Panama. Westport, CT: Greenwood Press.

Thomas, Robert. 1997. 'Roberto Sanchez Vilella, 84, Puerto Rican Governor, Dies.' The New York Times, March 26. Available at: http://www.nytimes.com/1997/03/26/us/roberto-sanchez-vilella84-puerto-rican-governor-dies.html, accessed March 10, 2015.

Wasniewski, Matthew, ed. 2013. Hispanic Americans in Congress, 1822-2012. Washington, DC: Government Printing Office. Available at: http://www.gpo.gov/fdsys/pkg/GPO-CDOCdoc225/contentetail.html, accessed June 12, 2015.

Weber, Max. 1922 [1978]. Economy and Society: An Outline of Interpretive Sociology. Edited by Guenther Roth and Claus Wittich. Berkeley, CA: University of California Press.

Zúñiga, Carlos Iván. 2006. 'Las facultades extraordinarias.' La Prensa, January 14. Available at: $\mathrm{http}: / /$ mensual.prensa.com/mensual/contenido/2006/01/14/hoy/opinion/466405.html, accessed March 10, 2015.

Zúquete, José Pedro. 2008. 'The Missionary Politics of Hugo Chávez.' Latin American Politics and Society, 50(1): 91-121. 